\title{
Simulating cheatgrass (Bromus tectorum) invasion decreases access to food resources for small mammals in sagebrush steppe
}

\section{Authors: Daniel A. Bachen, Andrea R. Litt, and Claire N. Gower}

The final publication is available at Springer via http://dx.doi.org/10.1007/s10530-018-1701-8

Bachen, Daniel A. , Andrea R. Litt, and Claire N. Gower. "Simulating cheatgrass (Bromus tectorum) invasion decreases access to food resources for small mammals in sagebrush steppe." Biological Invasions 20, no. 9 (March 2018): 2301-2311. DOI:10.1007/s10530-018-1701-8.

Made available through Montana State University's $\underline{\text { ScholarWorks }}$ scholarworks.montana.edu 


\title{
Simulating cheatgrass (Bromus tectorum) invasion decreases access to food resources for small mammals in sagebrush steppe
}

\author{
Daniel A. Bachen $(\mathbb{D} \cdot$ Andrea R. Litt - Claire N. Gower
}

\begin{abstract}
Invasions by nonnative plants can alter the abundance of native animals, yet we know little about the mechanisms driving these changes. Shifts in vegetation characteristics resulting from nonnative plants can alter availability of food resources, predation risk, and foraging efficiency (both the access to and ability to find food), each providing a potential mechanism for documented changes in animal communities and populations in invaded systems. Cheatgrass (Bromus tectorum) is a nonnative grass that invades sagebrush steppe, resulting in declines in some small mammal populations. We examined whether changes in structural characteristics associated with cheatgrass invasion could alter foraging by small mammals, providing a potential mechanism for documented population declines. We quantified
\end{abstract}

differences in vegetation structure between native and cheatgrass-invaded sagebrush steppe, then experimentally added artificial structure in native areas to simulate these differences. We placed grain at foraging stations and measured the amount removed by small mammals nightly. Adding litter at depths approximating invasion by cheatgrass reduced the average amount of grain removed in 2 of 3 study areas, but increasing stem density did not. Based on this experiment, the deeper litter created by cheatgrass invasion may increase costs to small mammals by decreasing foraging efficiency and access to existing food resources, which may explain population-level declines in small mammals documented in other studies. By isolating and identifying which structural attributes of cheatgrass invasion are most problematic for small mammals, land managers may be able to design treatments to efficiently mitigate impacts and restore invaded ecosystems.

\section{Introduction}

Invasions by nonnative plants can substantially alter vegetation composition and structure, with potential 
consequences for native animals (Vilà et al. 2011). Although the effects of nonnative plants on the abundance and diversity of animals have been wellstudied in many systems (reviewed in Pyšek et al. 2012), we know relatively little about the mechanisms driving these changes (Levine et al. 2003; Litt and Pearson 2013). Developing a mechanistic understanding may provide insights about potential management treatments and can increase our basic knowledge of how animals use the physical structure of their environment to find and acquire resources. Given that nonnative plants are found in most ecosystems and the distributions of some of these species are shifting with changing climate patterns (e.g., Bradley 2009), this information is essential for conservation.

In ecosystems dominated by native plants, vegetation composition and structure can shape the foraging behavior of animals, by providing food resources (or the habitat for those food resources), as well as the cover that affects predation risk and foraging efficiency (Rosenzweig 1973; Cody 1981; Arnan et al. 2007; Garden et al. 2007). Ideally, animals forage in areas where the benefits (e.g., harvest rate, nutrient acquisition) outweigh the costs (e.g., predation risk, searching, handling/processing), moving to new patches when this balance is no longer beneficial (Brown 1988). Invasion by nonnative plants can influence many aspects of this balance, by altering availability of food resources, predation risk, and foraging efficiency (both the access to and ability to find food); each of these effects provides a potential mechanism for documented changes in animal communities and populations in invaded systems.

Nonnative plants can alter food resources for animals, directly and indirectly. Some nonnative plants create a dense monoculture, displacing palatable native plants, arthropods, or other food resources (Ortega et al. 2006; Litt et al. 2014). Alternatively, some nonnative plants may provide additional, novel food resources (e.g., seeds and fruits, Mattos et al. 2013) or create conditions that increase abundance of other prey items (e.g., arthropod prey, Pearson and Fletcher 2008; Ostoja and Schupp 2009; Pearson 2009, 2010).

Numerous researchers have used experimental manipulations to demonstrate that vegetation cover and complexity play essential roles in the foraging behavior of small mammals (e.g., Rosenzweig 1973; Thompson 1982; Simonetti 1989); studies occurring in invaded areas echo these findings. Specifically, changes in vegetation structure that result from plant invasions alter predation risk perceived by small mammals (Mattos and Orrock 2010; Dutra et al. 2011; Johnson and De León 2015; Ceradini and Chalfoun 2017; Guiden and Orrock 2017). To make these assessments, researchers have compared foraging activity of small mammals, often by measuring the amount of seed removed from/remaining in food patches or trays in areas with and without the plant invader (e.g., Mattos and Orrock 2010; Johnson and De León 2015; Ceradini and Chalfoun 2017). Measuring the depletion of food patches to assess foraging activity assumes that animals stop foraging when the costs exceed the benefits (Brown 1988; reviewed in Verdolin 2006).

Vegetation structure also can influence animal movement (Crist et al. 1992; Vásquez et al. 2002), with subsequent effects on foraging efficiency if animals are less able to find and access food resources. Dense stands of nonnative grasses impede movement of small mammals (Rieder et al. 2010). Reduced movement ability could lead to reluctance or inability of animals to exploit food resources in invaded areas, but this potential mechanism has not yet been studied.

Cheatgrass (Bromus tectorum) is a nonnative grass that impacts small mammals by altering the vegetation structure and food resources. This grass can alter xeric ecosystems by creating dense, single-species stands (Rieder et al. 2010). Approximately $20 \%$ of the sagebrush steppe in the Great Basin is dominated by monocultures of cheatgrass, such that re-establishment of native perennial plants is nearly impossible (Knapp 1996). Cheatgrass also has invaded outside of the Great Basin and is present across much of the Northern Rockies and into the Northern Great Plains (Lesica et al. 2012); risk of invasion is predicted to increase with changes in precipitation and winter temperature due to climate change (Bradley 2009). Vegetation in sagebrush steppe typically is characterized by heterogeneous structure created by a diversity of plants such as bryophytes, forbs, and bunchgrasses, as well as scattered sagebrush shrubs (Young and Evans 1973). Cheatgrass invades and produces a persistent litter layer and dense stems that fill in the interspace between shrubs, creating a more dense and homogeneous vegetation structure (Young and Evans 1973). 
Abundance of some small mammals decreases with increased dominance of cheatgrass in sagebrush steppe ecosystems (Larrison and Johnson 1973; Gano and Rickard 1982; Ostoja and Schupp 2009; Hall 2012; Freeman et al. 2014), but the mechanisms driving these changes are understudied (but see Lucero et al. 2015; Ceradini and Chalfoun 2017). Cheatgrass may affect abundance of food resources for small mammals by displacing native plants (Young and Evans 1973; Knapp 1996) and altering abundance of some groups of arthropods (Rickard 1970; Ostoja and Schupp 2009). Cheatgrass seeds are more abundant in invaded ecosystems, but are not likely preferred food items for small mammals (Connolly et al. 2014; Lucero et al. 2015). Changes in abundance of food could be one mechanism driving changes in abundance of native animals that is associated with cheatgrass invasion (Gano and Rickard 1982; Rieder et al. 2010; Lucero et al. 2015). Increased vegetation cover and structure also could increase the perceived risk of predation (Ceradini and Chalfoun 2017), in part because avoiding predators could be more difficult (Rieder et al. 2010). Alternatively, increased structure and cover could provide protection from predators and facilitate foraging in these refugia (Orrock et al. 2004). Changes in vegetation cover and structure with cheatgrass invasion also may impede movement of small mammals (Gano and Rickard 1982; Rieder et al. 2010; Bachen 2014), which could alter access to food resources and increase the time and energy needed to find food. Altered costs of foraging (e.g., perceived predation risk and foraging efficiency) may provide additional mechanistic explanations for changes in abundance of small mammals documented with cheatgrass (Gano and Rickard 1982; Rieder et al. 2010; Ceradini and Chalfoun 2017).

We designed a manipulative experiment to evaluate whether changes in vegetation structure affect foraging by small mammals, as a potential mechanism driving population changes in invaded areas. We also measured and compared vegetation characteristics in areas of native sagebrush steppe and areas dominated by cheatgrass. Because cheatgrass increases both stem density and litter depth (Young and Evans 1973), our primary goal was to quantify how changes in these specific structural characteristics (in isolation and combined) affect the trade-offs small mammals face when foraging. By separating the structural changes that result from cheatgrass invasion, we sought to make our findings more generalizable to other nonnative plants or other anthropogenic factors that result in changes to vegetation structure. We hypothesized that increased structure could decrease an animal's ability to access food and forage efficiently, but that these costs could be mitigated if the structure also provides sufficient cover to reduce perceived predation risk, although we did not explicitly quantify this risk.

\section{Methods}

Study areas

We quantified vegetation attributes and conducted foraging trials in 3 areas in southwestern and central Montana during the summers of 2012 and 2013 (Fig. 1). Although these areas were geographically separate, all were shrublands dominated by big sagebrush (Artemisia tridentata). In 2012, we collected data on the Montana Fish, Wildlife and Parks (MFWP) Blacktail Wildlife Management Area (WMA) (hereafter Blacktail area), $50 \mathrm{~km}$ southeast of Dillon in southwestern Montana. In 2013, we collected data in 2 areas in central Montana: (1) Bureau of Land Management (BLM) land approximately $40 \mathrm{~km}$ northeast of Roundup, Montana (hereafter Roundup area) and (2) on the MFWP Yellowstone WMA, east of Billings, Montana (hereafter Yellowstone area). All study areas had expanses of sagebrush steppe dominated by native plants and the small mammal community was dominated ( $\geq 60 \%$ ) by deer mice (Bachen 2014).

In each of these study areas, we randomly selected sites that were $\geq 100 \mathrm{~m}$ from roads or other vegetation communities to avoid edge effects. To select sites, we generated random locations across the study areas using GIS and visited each to determine if the site was within sagebrush steppe and met our criteria for distance from roads and other habitat types; we considered alternate locations if these conditions were not met. In 2012, we established 18, $80 \times 80$-m sites at the Blacktail area. We changed our design in 2013 and created 27, $30 \times 40-\mathrm{m}$ sites, 14 at the Roundup and 13 at the Yellowstone areas (Fig. 2). Within each site, we established a grid of regularly-spaced, $10 \times 10$-m subplots (Blacktail: 64 subplots per site, Roundup and Yellowstone: 12 subplots/site). We set up one vegetation quadrat (Observational Study- 
Fig. 1 The locations of our study areas within the state of Montana, in relation to freeways. Coverage of sagebrush steppe across the state is shown in grey

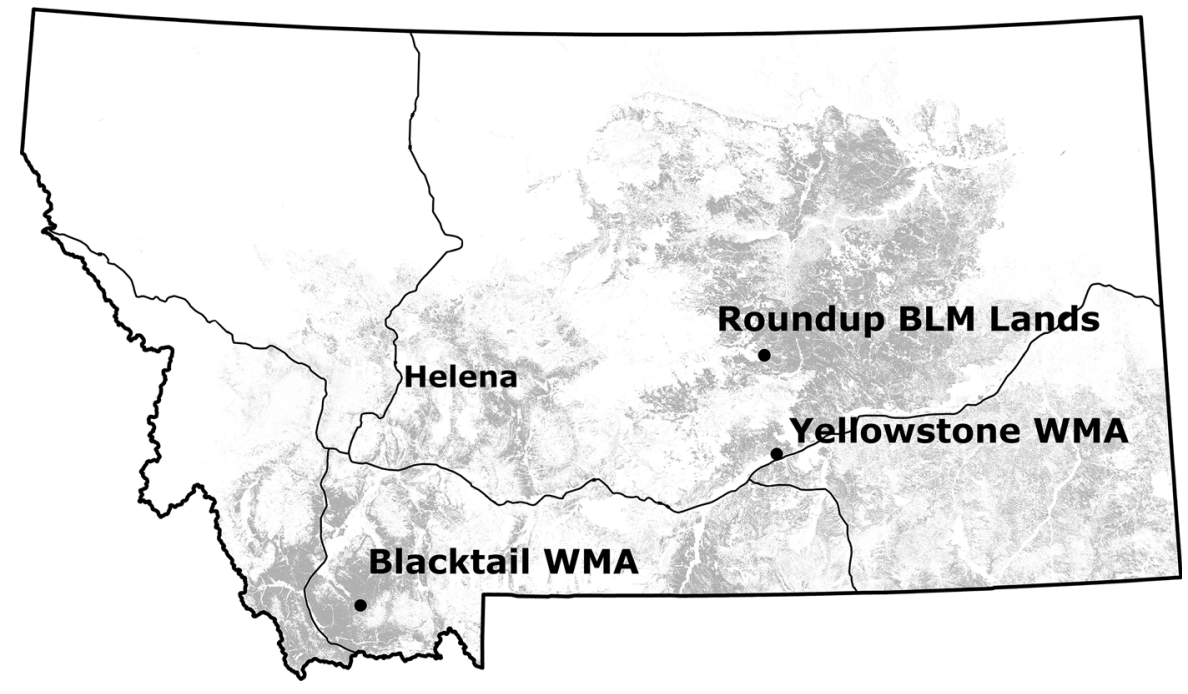

\section{a Site}

$80 \mathrm{~m} \times 80 \mathrm{~m}$

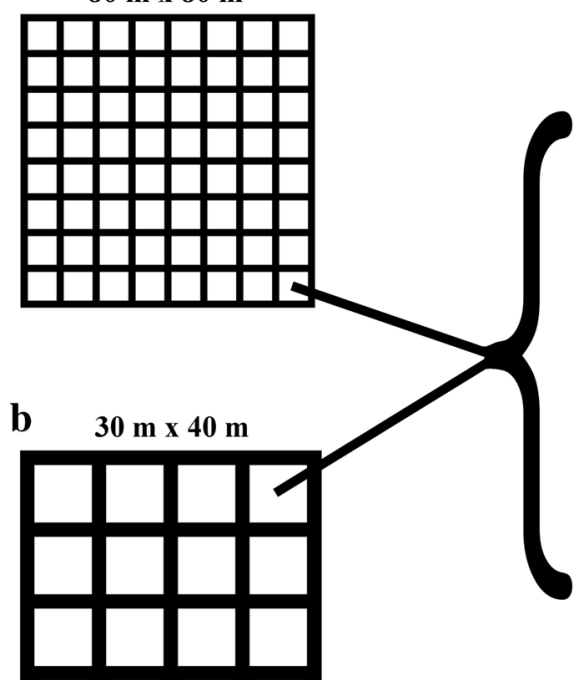

Fig. 2 Site and subplot design for foraging experiments, southwest and central Montana, summers 2012 and 2013. In 2012, we used $80 \times 80 \mathrm{~m}$ sites for the Blacktail area (a) and in 2013, $30 \times 40 \mathrm{~m}$ sites for both the Roundup and Yellowstone areas (b). We used the same subplot design for all study areas. Within each subplot, we added artificial vegetation structure in a

Vegetation Characteristics) and one foraging station (Experiment-Foraging Trials) within each subplot (Fig. 2).

The change in study design in 2013 was guided by a power analysis using the 2012 data to assess the number of sites, subplots, and treatment replicates within each site required to detect a $1 \mathrm{~g}$ change in the

\section{Subplot}

$10 \mathrm{~m} \times 10 \mathrm{~m}$

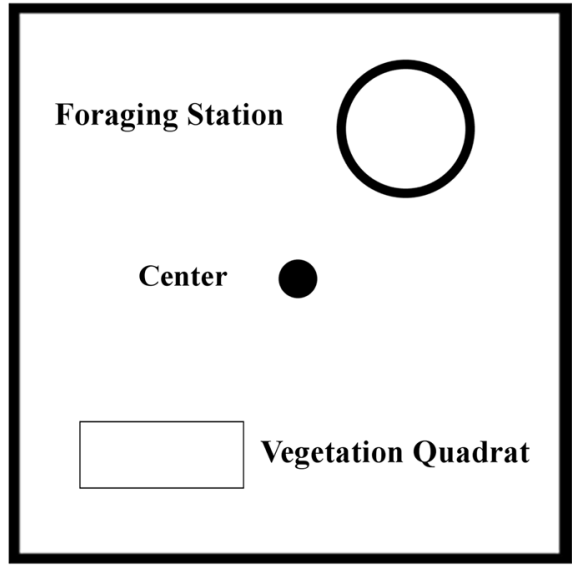

randomly-selected, 0.2-m diameter circle, and established a foraging station within this structure. We also quantified vegetation characteristics within a $0.2 \times 0.5-\mathrm{m}$ quadrat, selected at random within the subplot. This schematic is not drawn to scale

average amount of grain removed per night from a foraging station (Bachen 2014). Based on this information, we reduced the number of sites and subplots in 2013. 
Observational study—vegetation characteristics

We measured and compared vegetation characteristics in areas of native sagebrush steppe and areas dominated by cheatgrass. To quantify vegetation structure in native-plant dominated areas, we sampled vegetation in all 18 study sites (1088 subplots) in the Blacktail area in 2012 and all 27 study sites (156 subplots) in the Roundup and Yellowstone areas in 2013. To quantify vegetation structure in areas dominated by cheatgrass, we established 13 additional sites (156 subplots) in cheatgrass monocultures in 2013: 7 sites in the Roundup area and 6 in the Yellowstone area; the Blacktail area did not have cheatgrass. Within each subplot, we selected a $0.2 \times 0.5-\mathrm{m}$ quadrat that was $0.5 \mathrm{~m}$ from the subplot center in a random cardinal direction (Fig. 2). Here, we measured multiple vegetation characteristics: cover of all grasses, cheatgrass, forbs, bryophytes, woody debris (dead wood on the ground), litter, and bare ground to the nearest 5\% using visual approximation with a Daubenmire frame (Daubenmire 1959). We also measured litter depth, to the nearest $\mathrm{mm}$, at the center and each corner of the quadrat.

\section{Experiment-foraging trials}

We conducted foraging trials to quantify the effect of increasing litter depth and or stem density on foraging by small mammals. To each foraging station in the Blacktail area, we added artificial stems or litter to manipulate the vegetation structure, or left the station untreated to serve as a control. We randomly assigned structural treatments to stations by site: 6 sites treated with stem additions, 6 with litter additions, and 6 as untreated controls. Within each of the 12 treated sites, we added structure to every other station and left the remaining stations untreated (i.e., 32 treated and 32 control stations per site). We left all stations untreated in control sites (i.e., 64 control stations per site).

At each of the 27 sites within the Yellowstone and Roundup areas, we also added a treatment with both litter and stems placed at the same station, in addition to the separate litter and stem treatments. To allow for more robust comparisons, we assigned treatments to foraging stations within each site based on a randomized complete block design, instead of separating treatments by site. At each site, we randomly assigned each of the 3 treatments (added stems, added litter, or both in combination) to 3 stations ( 9 stations total) and retained 3 stations as untreated controls.

In both years of the study, we applied artificial structure in a circular area, $0.2 \mathrm{~m}$ in diameter, at each foraging station designated for treatment (Fig. 3). We located this circular foraging station $0.5 \mathrm{~m}$ from the center of the subplot in a random cardinal direction. To increase stem density, we added $15-\mathrm{cm}$ plastic whisker markers (Presco, Dallas, TX) at a density of approximately $7000 \mathrm{stems} / \mathrm{m}^{2}$, which is similar to densities in areas invaded by cheatgrass (Rieder et al. 2010). To create the desired density, we used the average number of "stems" per marker to calculate the appropriate number of markers that should be placed in the treatment area; we spaced these markers uniformly. To increase litter depth, we added landscape fabric (DeWhitt Company, Sikeston, MO), shredded to less than $0.5-\mathrm{cm}$ wide, to increase depth to $3 \mathrm{~cm}$, which is the litter depth we quantified in areas invaded by cheatgrass (D. Bachen, unpublished data). Although we did not expect these artificial treatments would mimic the structure of cheatgrass exactly, we believe that applying materials that are similar to the general structural characteristics at levels that are similar to what is found in invaded areas would allow us to draw inferences about the effects of each type of structural change (in isolation and combined) on foraging by small mammals.

After applying structural treatments, we added a Petri dish (4.7-cm diameter, Fisherbrand, Hampton, $\mathrm{NH}$ ) to hold grain at each foraging station. We placed wire mesh cages permeable to small mammals, made of cylinders of chicken wire (5-cm diameter) with a closed top and an open bottom, over each Petri dish (Fig. 3), to prevent foraging by larger mammals and birds. We positioned cages at foraging stations at least 2 weeks prior to initiating the experiments to allow animals to acclimate to their presence.

We placed $8 \mathrm{~g}$ of sweet feed, a mixture of barley, corn, and wheat soaked in molasses (hereafter, grain), in Petri dishes at each foraging station before dusk. We chose sweet feed, not to simulate available seed in either size or palatability, but rather to provide a high calorie, appealing food resource (Kelrick et al. 1986), increasing the benefits of foraging. The next morning, we collected the remaining grain from each station. We repeated this process for 5 consecutive nights at each site. We allowed grain collected from each station to dry naturally and recorded the weight to the 


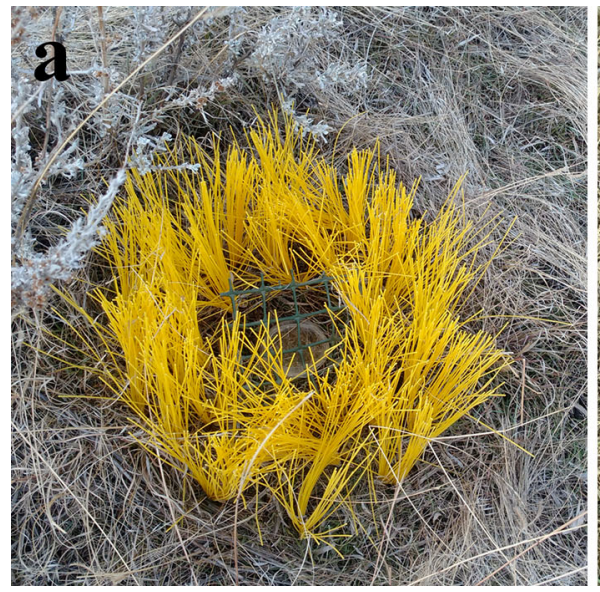

Fig. 3 A foraging station ( $0.2 \mathrm{~m}$ diameter circle) treated with artificial stems (a) and a foraging station without treatment, placed in native vegetation (b). We placed grain in the Petri dish

nearest $0.1 \mathrm{~g}$, to measure the amount of food animals removed overnight. Occasional thunderstorms washed grain out of the Petri dishes, invalidating the data for the previous night. Because of this, we removed 67 total site/nights from our analysis (Blacktail: 39 removed, 51 remaining; Roundup: 14 removed, 56 remaining; and Yellowstone: 14 removed, 51 remaining).

\section{Analyses}

Observational study—vegetation characteristics

We used linear mixed effects models to quantify differences in vegetation cover and litter depth between native plant-dominated and cheatgrass-invaded sites. We included dominant vegetation type (native or cheatgrass) as a fixed effect and incorporated a random effect for site to account for collecting multiple measurements at the subplot level within each site. To quantify differences in heterogeneity of vegetation cover and litter depth within each site, we calculated the coefficient of variation $(\mathrm{CV})$ corrected for small sample size for each vegetation characteristic within a site, and compared these statistics between native-dominated and cheatgrass-invaded sites using $t$-tests (Sokal and Rohlf 1995).

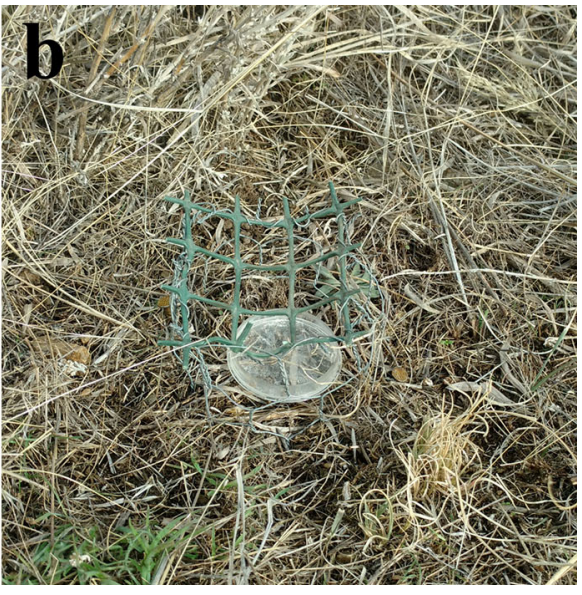

and covered the dish with a cage to prevent foraging by larger mammals and birds

Experiment—foraging trials

To quantify the effect of vegetation structure on foraging, we assessed differences among treatments in the mean amount of grain removed nightly from foraging stations using linear models. We analyzed data from 2012 and 2013 separately because of the differences in experimental design. We used the average difference in the amount of grain removed nightly from treatment stations and from control stations for each site as the response variable and included treatment ( 2 or 3 levels), time (night $1-5$ ), study area (for the 2013 data), and all possible interactions as explanatory variables. We predicted that foraging might increase over the duration of the experiment as more animals discovered the food resources and continued to forage at the station, so we initially explored a linear change in grain removed over time. To address the possibility that the relative increase in foraging may reach a threshold during the experimental period, we also considered a quadratic term for time.

To assess model assumptions, we plotted standardized residuals against the fitted values. We included covariates related to study design in all models, and tested whether to include interaction and quadratic terms. We compared model fit using a drop-indeviance test, including covariates with sufficient support $(P \leq 0.10)$. We completed all analyses in $\mathrm{R}$, using the $\mathrm{lm}$ function in the base package (R Core Team 2015). 


\section{Results}

Observational study—vegetation characteristics

Cheatgrass-invaded sites had more grass cover and deeper litter, but less shrub cover and bare ground, relative to native sagebrush steppe (Table 1). Grass cover was 39\% higher (95\% CI 29-49\%), litter was $2.8 \mathrm{~cm}$ deeper $(1.7-3.9 \mathrm{~cm})$, shrub cover was $25 \%$ lower (19-30\%), and bare ground was $23 \%$ lower (18-30\%) in cheatgrass-invaded sites, compared to native sagebrush steppe. Cover of shrubs, grasses, bryophytes, woody debris, and litter, as well as litter depth were more spatially homogeneous in cheatgrassdominated sites than in native sagebrush steppe (Table 2). We did not detect differences in spatial heterogeneity of cheatgrass, forb, or bare ground cover (Table 2).

\section{Experiment-foraging trials}

We found evidence that increasing litter depth affected the average amount of grain removed from foraging stations relative to untreated controls, although the direction and magnitude of the effect differed by study area (Tables 3, 4, Fig. 4). When we added litter, the average amount of grain removed by small mammals decreased by $0.8 \mathrm{~g}$ (95\% CI $0.4-1.3 \mathrm{~g})$ in the Yellowstone area and by $1.4 \mathrm{~g}$ in the Blacktail area (0.6 to $-2.3 \mathrm{~g})$, but increased by $0.5 \mathrm{~g}(0.1-1.0 \mathrm{~g})$ in the Roundup area (Table 3). We found little evidence that increasing stem density affected the average

Table 1 Differences in vegetation characteristics (\% cover and litter depth) between cheatgrass and native sagebrush steppe (difference $=$ cheatgrass - native sagebrush, $n=27$ sites, 324 amount of grain removed each night for any of the study areas (Tables 3, 4, Fig. 4). The effect of increasing both litter depth and stem density simultaneously was similar to stations where we only increased the density of stems (Fig. 4).

\section{Discussion}

Ideally, animals should prefer abundant, high-quality food sources that can be accessed at relatively low cost (Pyke 1984; Ydenberg et al. 1994), but novel vegetation characteristics produced by plant invasions can greatly alter these tradeoffs (Mattos and Orrock 2010; Dutra et al. 2011; Johnson and De León 2015; Ceradini and Chalfoun 2017; Guiden and Orrock 2017). We found that sites dominated by cheatgrass had more grass and deeper litter, as well as less bare ground and shrub cover, relative to native sagebrush steppe, which could affect foraging behavior of small mammals by decreasing available food (Connolly et al. 2014; Lucero et al. 2015), increasing predation risk (Thompson 1982; Ceradini and Chalfoun 2017), decreasing access to food, or some combination of these mechanisms. We aimed to simulate some of these structural changes in our experiments and separated changes in horizontal (litter) and vertical (stem density) vegetation structure, to investigate their possible effects on foraging choices of small mammals.

Differences in the effects of litter and stem treatments suggest that the nature of structural changes (vertical/standing [e.g., stem density] or horizontal/

subplots) obtained from the inferential model, Yellowstone and Roundup sites, central Montana, summer 2013

\begin{tabular}{|c|c|c|c|c|c|}
\hline Covariate & Estimate & $95 \% \mathrm{C}$ & & $t_{27}$ & $P$ \\
\hline Cheatgrass $(\%)$ & 67 & 55 & 79 & 10.73 & $<0.001$ \\
\hline Shrubs (\%) & -25 & -31 & -19 & -8.90 & $<0.001$ \\
\hline All grasses $(\%)$ & 39 & 29 & 49 & 10.31 & $<0.001$ \\
\hline Forbs $(\%)$ & 1 & -3 & 5 & 0.56 & 0.580 \\
\hline Bryophytes (\%) & -3 & -5 & -1 & -4.33 & $<0.001$ \\
\hline Woody debris (\%) & -2 & -4 & 0 & -2.64 & 0.014 \\
\hline Litter $(\%)$ & 15 & 7 & 23 & 3.49 & 0.002 \\
\hline Bare ground $(\%)$ & -23 & -29 & -17 & -7.76 & $<0.001$ \\
\hline Litter depth $(\mathrm{cm})$ & 2.8 & 1.8 & 3.8 & 5.17 & $<0.001$ \\
\hline
\end{tabular}


Table 2 Differences in heterogeneity of vegetation between cheatgrass and native sagebrush steppe (difference = cheatgrass-native sagebrush), as measured by CV (\%, corrected for small sample size), Yellowstone and Roundup sites, central Montana, summer 2013

\begin{tabular}{|c|c|c|c|c|c|}
\hline Covariate & Difference $(\%)$ & $95 \% \mathrm{CI}$ & & $t_{27}$ & $P$ \\
\hline Cheatgrass $(\%)$ & -56 & -118 & 6 & -1.36 & 0.185 \\
\hline Shrubs (\%) & -81 & -99 & -63 & -2.66 & 0.013 \\
\hline All grasses (\%) & -47 & -80 & -14 & -5.24 & $<0.001$ \\
\hline Forbs $(\%)$ & -39 & -113 & 35 & -1.08 & 0.290 \\
\hline Bryophytes (\%) & -100 & -190 & -10 & -2.82 & 0.009 \\
\hline Woody debris (\%) & -172 & -227 & -10 & -3.91 & 0.001 \\
\hline Litter (\%) & -86 & -154 & -18 & -3.13 & 0.004 \\
\hline Bare ground $(\%)$ & -35 & -119 & 49 & -1.05 & 0.305 \\
\hline Litter depth $(\mathrm{cm})$ & -71 & -100 & -42 & -5.14 & $<0.001$ \\
\hline
\end{tabular}

Negative values indicate invaded areas are more homogeneous than native sagebrush steppe

Table 3 Estimated effects of explanatory variables from our inferential model quantifying the effect of structural characteristics on the amount of grain removed from foraging stations, Blacktail study area, southwestern Montana, summer 2012

\begin{tabular}{|c|c|c|c|c|c|c|}
\hline Covariate & Estimate & $95 \% \mathrm{CI}$ & & $d f$ & $t_{61}$ & $P$ \\
\hline (Intercept) & 2.47 & 1.87 & 3.07 & 2842 & 8.23 & $<0.001$ \\
\hline Litter depth & 0.36 & -0.26 & 0.99 & 2838 & 1.18 & 0.242 \\
\hline Stem density & -0.37 & -0.91 & 0.16 & 2838 & -1.40 & 0.167 \\
\hline Time (days) & 0.14 & -0.22 & 0.50 & 31 & 0.77 & 0.447 \\
\hline Time $^{2}$ (days) & 0.07 & 0.02 & 0.13 & 31 & 2.57 & 0.013 \\
\hline Litter $\times$ time & -0.28 & -0.45 & -0.11 & 2838 & -3.35 & 0.001 \\
\hline Stems $\times$ time & 0.06 & -0.09 & 0.21 & 2838 & 0.78 & 0.427 \\
\hline
\end{tabular}

The model is parameterized with foraging stations in native vegetation as the reference level (intercept)

accumulated on the ground [e.g., litter]) is important to understand potential changes in foraging behavior of small mammals. Although we expected increased stem density to hinder movement of animals, any potential impediment did not alter the amount of grain foraged. We expected increased litter would make finding and accessing food more difficult and we documented reductions in the amount of grain foraged. Both structural treatments could have altered perceived predation risk and thus, how much time animals were willing to spend accessing food. However, in a related study, Bachen (2014) found that deer mice did not hide in either structural treatment to seek cover from a simulated predator until litter depth reached $7 \mathrm{~cm}$ and stem densities reached $15,000 \mathrm{stems} / \mathrm{m}^{2}$. Based on these data, we think it is unlikely that either treatment was applied at a great enough density to create sufficient protective cover during the current study. Given that shrubs still represent a dominant structural component in our native sagebrush steppe sites, our added structure may be less likely to reduce perceived predation risk (although we found less shrub cover in cheatgrassdominated areas). Ceradini and Chalfoun (2017) also found that cheatgrass did not reduce the perceived predation risk for small mammals in a semi-desert grassland, relative to cover provided by shrubs. As such, decreased ability to find or access food are the most likely mechanisms for our results. However, the effects of litter were mitigated when applied in combination with increased stem density, suggesting that some other mechanism, such as predation risk, also may be acting within our system.

Structural conditions created by litter may have increased the time and energy required to access food, such that costs outweighed benefits, leading animals to 
Table 4 Estimated effects of explanatory variables from our inferential model quantifying the effect of structural characteristics on the amount of grain removed from foraging stations, Yellowstone and Roundup study areas, central Montana, summer 2013

\begin{tabular}{|c|c|c|c|c|c|c|}
\hline Covariate & Estimate & $95 \% \mathrm{CI}$ & & $d f$ & $t$ & $P$ \\
\hline (Intercept) & 1.07 & 0.52 & 1.64 & 669 & 3.79 & 0.002 \\
\hline Litter depth & 0.51 & 0.05 & 0.98 & 631 & 2.18 & 0.029 \\
\hline Stems density & 0.41 & -0.11 & 0.82 & 631 & 1.50 & 0.134 \\
\hline Litter and stems & 0.41 & -0.06 & 0.87 & 631 & 1.72 & 0.086 \\
\hline Time (days) & 0.09 & 0.01 & 0.16 & 38 & 2.23 & 0.026 \\
\hline Study area & 0.62 & 0.85 & 2.40 & 12 & 4.13 & $<0.001$ \\
\hline Litter $\times$ study area & -1.33 & -1.97 & -0.69 & 631 & -4.05 & $<0.001$ \\
\hline Stems $\times$ study area & -0.50 & -1.14 & 0.15 & 631 & -1.52 & 0.128 \\
\hline Litter and stems $\times$ study area & -0.79 & -1.44 & -0.15 & 631 & -2.41 & 0.016 \\
\hline
\end{tabular}

The model is parameterized with foraging stations in native vegetation as the reference level (intercept)

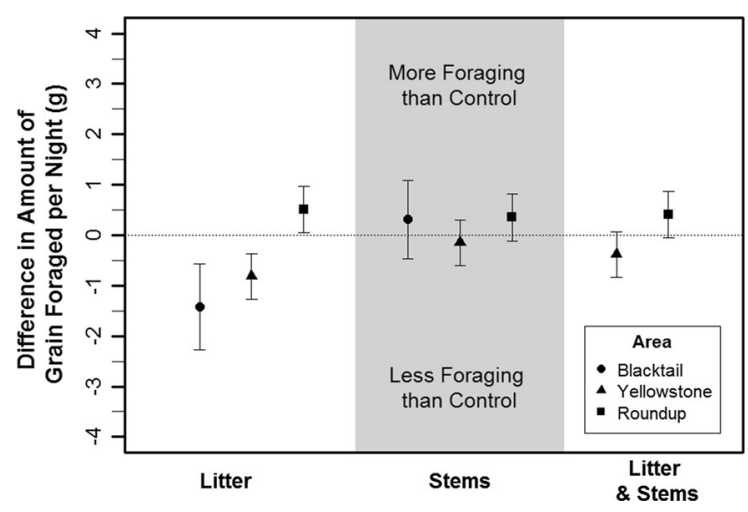

Fig. 4 Differences in the average amount of grain removed per night (and 95\% CIs from inferential models) with added structure, relative to untreated controls in native vegetation (reference line at 0 ). Values above the reference line indicate that small mammals removed more grain from treatment stations and values below the reference line indicate small mammals removed less grain from treatment stations, relative to control stations. Estimates for Blacktail correspond to the fifth night of foraging to accommodate the time $\times$ treatment interaction in the model

reduce or cease foraging and remove less grain (Brown 1988). However, we found different results in one study area (Roundup), where inherent differences in biotic factors such as the community composition of small mammals, vegetation, and predators, as well as abiotic factors like elevation, soil type, and aspect may have altered tradeoffs (Mitchell et al. 1990). All study sites were dominated by deer mice and the vegetation characteristics we would expect to affect foraging, such as litter depth and cover of forbs and shrubs were not consistently different among our study areas (Bachen 2014). Although we assumed that the abundance and accessibility of food were relatively constant within sites, differences in food resources among study areas also could explain variation in responses. Larger sample sizes may have been necessary to detect existing differences, but we tried to address this by using a power analysis to inform the design of our 2013 experiments.

Other researchers have used artificial structure to experimentally test how changes in vegetation structure can affect behavior of small mammals (Thompson 1982; Simonetti 1989; Mattos and Orrock 2010); these designs can provide strong inference by reducing confounding factors. Both Thompson (1982) and Mattos and Orrock (2010) used artificial shrubs to test how refugia influenced foraging behavior, when isolated from changes in food resources. Simonetti (1989) found that small mammals were more likely to enter artificial structure simulating shrubs than artificial structure simulating basal herbs. Multiple changes in structural components typically are intertwined in other studies; we sought to build on previous studies and make our inferences more generalizable by examining the effects of each structural component in isolation (and in combination). Although artificial structure can isolate effects of specific structural attributes, inferences from these experiments can be biased if artificial materials do not mimic the actual structure adequately. Although we did not explicitly test how well our artificial structure treatments mimicked cheatgrass, our treatments were based on prior characterizations of the density of stems and depth of litter found in cheatgrass monocultures (Rieder et al. 2010, D. Bachen unpublished data). 
We also used an unnatural food resource for our foraging trials, which also is similar to other foraging studies. We used a mixture of corn, barley, and rolled oats; other researchers have used millet (Panicum milianceum, Mattos and Orrock 2010) or sunflower seeds (Helianthus annuus, Johnson and De León 2015; Ceradini and Chalfoun 2017). Kelrick et al. (1986) studied a small mammal community dominated by deer mice in sagebrush steppe and found that nocturnal seed predators preferentially foraged on seeds with higher calories and preferred millet over native seeds. Although we did not assess whether the type of grains we used for our experiment were preferred over native seeds, we used larger seeds from commercial sources that we assume provide more calories. Based on optimal foraging, large, resource-rich food items should be highly desired (Pyke 1984) and provide beneficial foraging choices. Given that the seeds of native plants in our system are generally smaller than the grain we used, we would expect costs of foraging to far outweigh the benefits, magnifying the effects we observed with changes in vegetation structure.

Species that rely on sagebrush-dominated ecosystems as critical habitat, such as greater sage-grouse (Centrocercus urophasianus, Crawford et al. 2004), also could be impacted by dense vegetation structure created by plant invasions. Sage grouse chicks are relatively small and they do not have sleek bodies that would facilitate quick movement through dense vegetation (Rieder et al. 2010). Because sage grouse chicks also are particularly vulnerable to decreases in food resources (Gregg and Crawford 2010), reducing their ability to access food could have population-level implications. As a result, we suggest that changes in foraging resulting from novel structural characteristics of invasive plants should be evaluated for other vertebrate species, particularly species of management concern.

Many invasive plants are well-established (Vitousek et al. 1996) and removal or even reduction of these plants on a landscape scale is improbable or impossible, requiring novel approaches for management and conservation. Understanding the mechanisms by which nonnative plants affect animals may provide insights about alternative ways to reduce these impacts (Levine et al. 2003) by informing restoration and mitigation efforts. Our research suggests that deeper litter may impede foraging by small mammals, so designing treatments that focus specifically on modifying this structural component may help managers mitigate the effects of cheatgrass. Our findings also contribute more broadly to our understanding about factors that drive foraging in small mammals and could be applicable for other anthropogenic activities that modify vegetation structure.

Acknowledgements We thank Dr. Megan Higgs for her assistance throughout this project. Comments from Dr. Higgs and several anonymous reviewers greatly improved this manuscript. We also appreciate financial and logistical support from the Department of Ecology at Montana State University, Montana Fish, Wildlife, and Parks, the Montana Chapter of The Wildlife Society, the Montana Institute on Ecosystems, and the Bureau of Land Management.

\section{References}

Arnan X, Rodrigo A, Retana J (2007) Uncoupling the effects of shade and food resources of vegetation on Mediterranean ants: an experimental approach at the community level. Ecography 30:161-172

Bachen DA (2014) Cheatgrass invasion of sagebrush steppe: Impacts of vegetation structure on small mammals. Thesis, Montana State University

Bradley BA (2009) Regional analysis of the impacts of climate change on cheatgrass invasion shows potential risk and opportunity. Glob Change Biol 15:196-208

Brown JS (1988) Patch use as an indicator of habitat preference, predation risk, and competition. Behav Ecol Sociobiol 22:37-47

Ceradini JP, Chalfoun AD (2017) When perception reflects reality: non-native grass invasion alters small mammal risk landscapes and survival. Ecol Evol 7:1823-1835

Cody ML (1981) Habitat selection in birds: the role of vegetation structure, competitors and productivity. Bioscience 31:107-113

Connolly BM, Pearson DE, Mack RN (2014) Granivory of invasive, naturalized, and native plants in communities differentially susceptible to invasion. Ecology 95:1759-1769

Crawford JA, Olson RA, West NE, Mosley JC, Schroder MA, Whitson TD, Miller RF, Gregg MA, Boyd CS (2004) Ecology and management of sage-grouse and sage-grouse habitat. Rangel Ecol Manag 57:2-9

Crist TO, Guertin DS, Wiens JA, Milne BT (1992) Animal movement in heterogeneous landscapes: an experiment with Eleodes beetles in shortgrass prairie. Funct Ecol 6:536-544

Daubenmire R (1959) A canopy-coverage method of vegetation analysis. Northwest Sci 33:43-64

Dutra HP, Barnett K, Reinhardt JR, Marquis RJ, Orrock JL (2011) Invasive plant species alters consumer behavior by providing refuge from predation. Oecologia 166:649-657

Freeman ED, Sharp TR, Larson RT, Knight RN, Slater SJ, McMillan BR (2014) Negative effects of an exotic grass 
invasion on small mammal communities. PLoS ONE 9:e108843. https://doi.org/10.1371/journal.pone.0108843

Gano KA, Rickard WH (1982) Small mammals of a bitterbrushcheatgrass community. Northwest Sci 56:1-8

Garden JG, McAlpine CA, Possingham HP, Jones DN (2007) Habitat structure is more important than vegetation composition for local-level management of native terrestrial reptile and small mammal species living in urban remnants: a case study from Brisbane, Australia. Austral Ecol 32:669-685

Gregg MA, Crawford JA (2010) Survival of greater sage-grouse chicks and broods in the northern Great Basin. J Wildl Manag 73:904-913

Guiden PW, Orrock JL (2017) Invasive exotic shrub modifies a classic animal-habitat relationship and alters patterns of vertebrate seed predation. Ecology 98:321-327

Hall LK (2012) Effect of cheatgrass on abundance of the North American deer mouse (Peromyscus maniculatus). Southwest Nat 57:166-169

Johnson MD, De León YL (2015) Effect of an invasive plant and moonlight on rodent foraging behavior in a coastal dune ecosystem. PLoS ONE 10(2):e0117903

Kelrick MI, MacMahon JA, Parmenter RR, Sisson DV (1986) Native seed preferences of shrub-steppe rodents, birds and ants: the relationships of seed attributes and seed use. Oecologia 68:327-337

Knapp PA (1996) Cheatgrass (Bromus tectorum L.) dominance in the Great Basin Desert: history, persistence, and influences to human activities. Glob Environ Change 6:37-52

Larrison EJ, Johnson DR (1973) Density changes and habitat affinities of rodents of shadescale and sagebrush associations. Great Basin Nat 33:255-264

Lesica P, Lavin MT, Stickney PF (2012) Manual of Montana Vascular Plants. BRIT Press, Fort Worth, p 771

Levine JM, Vilà M, D’Antonio CM, Dukes JS, Grigulis K, Lavorel S (2003) Mechanisms underlying the impacts of exotic plant invasions. Proc R Soc Lond Ser B Biol Sci 270:775-781

Litt AR, Pearson DE (2013) Non-native plants and wildlife in the intermountain west. Wildl Soc Bull 37(3):517-526

Litt AR, Cord EE, Fulbright TE, Schuster GL (2014) Effects of invasive plants on arthropods. Conserv Biol 28:1532-1549

Lucero JE, Allen PS, McMillan BR (2015) Increased primary production from an exotic invader does not subsidize native rodents. PLoS ONE 10:e0131564

Mattos KJ, Orrock JL (2010) Behavioral consequences of plant invasion: an invasive plant alters rodent antipredator behavior. Behav Ecol 21:556-561

Mattos KJ, Orrock JL, Watling JI (2013) Rodent granivores generate context-specific seed removal in invaded and uninvaded habitats. Am Midland Nat 169:168-178

Mitchell WA, Abramsky Z, Kotler BP, Pinshow B, Brown JS (1990) The effect of competition on foraging activity in desert rodents: theory and experiments. Ecology 71:844-854

Orrock JL, Danielson BJ, Brinkerhoff RJ (2004) Rodent foraging is affected by indirect, but not by direct, cues of predation risk. Behav Ecol 15:433-437

Ortega YK, McKelvey KS, Six DL (2006) Invasion of an exotic forb impacts reproductive success and site fidelity of a migratory songbird. Oecologia 149:340-351
Ostoja SM, Schupp EW (2009) Conversion of sagebrush shrublands to exotic annual grasslands negatively impacts small mammal communities. Divers Distrib 15:863-870

Pearson DE (2009) Invasive plant architecture alters trophic interactions by changing predator abundance and behavior. Oecologia 159:549-558

Pearson DE (2010) Trait-and density-mediated indirect interactions initiated by an exotic invasive plant autogenic ecosystem engineer. Am Nat 176:394-403

Pearson DE, Fletcher RJ (2008) Mitigating exotic impacts: restoring deer mouse populations elevated by an exotic food subsidy. Ecol Appl 18:321-334

Pyke GH (1984) Optimal foraging theory: a critical review. Annu Rev Ecol Syst 15:523-575

Pyšek P, Jarošík V, Hulme PE, Pergl J, Hejda M, Schaffner U, Vilà M (2012) A global assessment of invasive plant impacts on resident species, communities and ecosystems: the interaction of impact measures, invading species' traits and environment. Glob Change Biol 18:1725-1737

R Core Team (2015) R: a language and environment for statistical computing. R Foundation for Statistical Computing, Vienna. http://www.R-project.org. Accessed 25 Oct 2015

Rickard WH (1970) Ground dwelling beetles in burned and unburned vegetation. J Range Manag 23:293-294

Rieder JP, Newbold TS, Ostoja SM (2010) Structural changes in vegetation coincident with annual grass invasion negatively impacts sprint velocity of small vertebrates. Biol Invasions 12:2429-2439

Rosenzweig ML (1973) Habitat selection experiments with a pair of coexisting heteromyid rodent species. Ecology 54:111-117

Simonetti JA (1989) Microhabitat use by small mammals in central Chile. Oikos 56:309-318

Sokal RR, Rohlf FJ (1995) Biometry: the principles and practice of statistics in biological research. WH. Freeman and Co., San Francisco

Thompson SD (1982) Structure and species composition of desert heteromyid rodent species assemblages: effects of a simple habitat manipulation. Ecology 63:1313-1321

Vásquez RA, Ebensperger LA, Bozinovic F (2002) The influence of habitat on travel speed, intermittent locomotion, and vigilance in a diurnal rodent. Behav Ecol 13:182-187

Verdolin JL (2006) Meta-analysis of foraging and predation risk trade-offs in terrestrial systems. Behav Ecol Sociobiol 60:457-464

Vilà M, Espinar JL, Hejda M, Hulme PE, Jarošík V, Maron JL, Pergl J, Schaffner U, Sun Y, Pyšek P (2011) Ecological impacts of invasive alien plants: a meta-analysis of their effects on species, communities and ecosystems. Ecol Lett 14:702-708

Vitousek PM, D’Antonio CM, Loope LL, Westbrooks R (1996) Biological invasions as global change. Am Sci 84:468-478

Ydenberg RC, Welham CVJ, Schmid-Hempel R, SchmidHempel P, Beauchamp G (1994) Time and energy constraints and the relationships between currencies in foraging theory. Behav Ecol 5:28-34

Young JA, Evans RA (1973) Downy brome: intruder in the plant succession of big sagebrush communities in the Great Basin. J Range Manag 26:410-415 